Insight, part of a Special Feature on Practicing Panarchy: Assessing Legal Flexibility, Ecological Resilience, and Adaptive Governance in U.S. Regional Water Systems Experiencing Climate Change

\title{
The role of law in adaptive governance
}

\author{
Barbara A. Cosens ${ }^{1,2}$, Robin K. Craig ${ }^{3,4}$, Shana Lee Hirsch ${ }^{2}$, Craig Anthony (Tony) Arnold ${ }^{5,6}$, Melinda H. Benson ${ }^{7}$, Daniel A. \\ $\underline{\text { DeCaro }}^{8}$, Ahjond S. Garmestani $^{9}$, Hannah Gosnell $^{10}, \underline{\text { J.B. Ruhl }}^{11}$ and Edella Schlager $^{12}$
}

\begin{abstract}
The term "governance" encompasses both governmental and nongovernmental participation in collective choice and action. Law dictates the structure, boundaries, rules, and processes within which governmental action takes place, and in doing so becomes one of the focal points for analysis of barriers to adaptation as the effects of climate change are felt. Adaptive governance must therefore contemplate a level of flexibility and evolution in governmental action beyond that currently found in the heavily administrative governments of many democracies. Nevertheless, over time, law itself has proven highly adaptive in western systems of government, evolving to address and even facilitate the emergence of new social norms (such as the rights of women and minorities) or to provide remedies for emerging problems (such as pollution). Thus, there is no question that law can adapt, evolve, and be reformed to make room for adaptive governance. In doing this, not only may barriers be removed, but law may be adjusted to facilitate adaptive governance and to aid in institutionalizing new and emerging approaches to governance. The key is to do so in a way that also enhances legitimacy, accountability, and justice, or else such reforms will never be adopted by democratic societies, or if adopted, will destabilize those societies. By identifying those aspects of the frameworks for adaptive governance reviewed in the introduction to this special feature relevant to the legal system, we present guidelines for evaluating the role of law in environmental governance to identify the ways in which law can be used, adapted, and reformed to facilitate adaptive governance and to do so in a way that enhances the legitimacy of governmental action.
\end{abstract}

Key Words: adaptive governance; administrative law; environmental governance; resilience; water law

\section{INTRODUCTION}

Law reflects the combined result of the many viewpoints, values, knowledge systems, information types, and power struggles that come into play in its making and is thus inherently integrative. Law reflects the values of society. Western legal systems adapt and respond to new challenges through the issue-by-issue evolution in the interpretation of the law by the judicial branch of government, through the problem-by-problem evolution of the law by the legislative branch, and through the policy evolution inherent in election cycles. Nevertheless, legal systems are also purposely structured to prefer the status quo by fostering stability and predictability. Thus, the checks and balances among the branches of government serve to slow the process of change and foster deliberation from multiple perspectives. As a result of this stabilizing structure, legal systems may pose barriers to adaptation.

If law is so rigid that it presents barriers to the adaptation necessary to sustain society as change accelerates because of the intersection of population growth, climate change, and other factors driving change, then the law itself must also change to allow adaptation within the longer term goal of stability (Green et al. 2015). It is our view that the law can and, in fact, must be made adaptive to facilitate and even trigger the emergence of adaptive governance and to aid in institutionalizing adaptive governance as it emerges. We came together to explore the role of law in achieving water governance that is capable of facilitating management, adaptation, and transformation in the face of climate change, i.e., law that is itself adaptive. While formulated in the context of water governance, the results of our analysis are broadly applicable. To this end, we present guidelines for evaluating the role of law in adaptive governance in the context of environmental governance.

\section{BACKGROUND AND APPROACH}

The quest to align the adjustments in the legal framework for environmental management with the understanding of a specific ecological system and the goals of its society is an inherently interdisciplinary problem. Communication and methodology are major challenges in interdisciplinary research and require the development of a common language and understanding of concepts (Repko 2011). Many of the terms we use have multiple meanings depending on context and disciplinary viewpoint. Rather than resolve these differences, we gave careful attention to choosing the particular usage that best fits our purpose and identifying the body of literature consistent with that usage. The terms "governance" (the means through which collective goals are chosen, decisions are made, and actions are taken to achieve those goals; Rogers and Hall 2003, UNSTT 2012) and "adaptive governance" (a "range of interactions between actors, networks, organizations, and institutions emerging in pursuit of a desired state for social-ecological systems;" Chaffin et al. 2014b) are central to this discussion. A full discussion of these terms and their relation to the concept of resilience (i.e., the capacity of a system to both resist and adapt to disturbance and still maintain the same structure and function; Holling 1973, Gunderson and Holling 2002, Walker et al. 2004, Walker and Salt 2006) is set forth in the introduction to this Special Feature.

\footnotetext{
${ }^{1}$ University of Idaho College of Law, ${ }^{2}$ Institute for Waters of the West, University of Idaho, ${ }^{3}$ Wallace Stegner Center for Land, Resources, University of Utah S.J. Quinney College of Law, ${ }^{4}$ University of Utah Global Change and Sustainability Center, ${ }^{5}$ Brandeis School of Law, Department of Urban \& Public Affairs, and Center for Land Use \& Environmental Responsibility, University of Louisville, ${ }^{6}$ UCLA School of Law, ${ }^{7}$ University of New Mexico, ${ }^{8}$ Department of Urban and Public Affairs and Department of Psychological and Brain Sciences, University of Louisville, ${ }^{9}$ U.S. Environmental Protection Agency, ${ }^{10}$ College of Earth, Ocean and Atmospheric Sciences, Oregon State University, ${ }^{11}$ Vanderbilt University Law School, ${ }^{12}$ School of Government and Public Policy, University of Arizona
} 
Table 1. Guidelines for inquiry into the role of law in adaptive governance.

\begin{tabular}{|c|c|c|}
\hline $\begin{array}{l}\text { Aspect of } \\
\text { government } \\
\text { governed by law }\end{array}$ & $\begin{array}{l}\text { Framework } \\
\text { component }^{\dagger}\end{array}$ & Descriptive guidelines for assessment of framework component \\
\hline \multirow[t]{3}{*}{ Structure } & Polycentricity & $\begin{array}{l}\text { Multiple centers of authority. Law controls the locus of authority for governmental entities. } \\
\text { - Redundancy: common management and decision-making functions at multiple scales. Redundancy increases } \\
\text { the likelihood that decisions can be made and implemented at the scale of a particular problem. } \\
\text { - Nesting: representation of decision-making and advisory bodies at lower levels in higher level entities. } \\
\text { Nesting allows the formation of ad hoc networks in response to surprise, and increases the potential for local } \\
\text { innovation within stable governance at a larger scale. } \\
\text { - Complementarity: if one decision body fails to act or acts inappropriately then another body can intervene. } \\
\text { - Subsidiarity: decision-making at the level closest to the resource as possible yet within the context of a } \\
\text { government at multiple scales that fosters the conditions for implementation of management decisions. } \\
\text { Subsidiarity increases the likelihood that local knowledge will be used, decisions will be tailored to specific } \\
\text { problems, and innovation may occur at the local level, supported by governance at larger scales. }\end{array}$ \\
\hline & Integration & $\begin{array}{l}\text { Integration of water resources management across sectors that influence water allocation, quality, and land } \\
\text { development, and integration of regulation of physically connected resources such as ground and surface } \\
\text { water. Integration reduces the possibility of unintended consequences. }\end{array}$ \\
\hline & Persistence & $\begin{array}{l}\text { Stability in representation and decision-making bodies to foster legitimacy and trust, potentially reducing } \\
\text { response time to surprise. }\end{array}$ \\
\hline
\end{tabular}
uncertainty and change.

Participatory Those affected have the right and resources to have a role in decision-making. For indigenous communities, this equates to the capacity for self-determination. Participatory capacity reduces the likelihood of marginalization of portions of society and increases the likelihood that all aspects of a system will be considered in decision making.

Process Legitimacy Acceptance of authority because it is perceived to be and is exercised appropriately. Legitimacy is necessary for public support of resource management and includes requirements for science-based decision-making, deliberation, accountability, transparency, consistency, stability, and review and recourse for those aggrieved by a governmental action.

Procedural justice Transparency, the right to seek review, and engagement at the appropriate level. Procedural justice is necessary to identify unintended consequences, check corruption, and to avoid uneven application of the burden of adaptation. For indigenous communities, procedural justice requires processes allowing engagement at the governmental level.

Problem-solving Authority and resources to use science and interest-based collaborative processes. Allows for the possibility of approach solutions that are beneficial to all, and contrasts with political and ideological approaches that are not subject to compromise.

Reflection and Resources for monitoring and a process for feedback and consideration of new information. The opportunity learning for reflection and learning assures that response to change will not be rote, and that society will evolve with the approach to management.

Balance stability Adaptation time frames that consider both the need for adjustment and the economic need for stability. and flexibility Balance of stability and flexibility recognizes that while adjustments must occur in the face of change, social systems and particularly economic systems require stability; both must be taken into account.

Dispute resolution Process for resolving conflict and making final, binding decisions on trade-offs regarding scarce resources. Dispute resolution is essential as water scarcity unfolds in the face of climate change. There may come a point when consensus is not possible and, unless a system for resolving issues is designed and agreed upon beforehand, conflict is likely.

Used to assess the role of law in adaptive governance.

Law is multifaceted. Therefore, as an interdisciplinary exercise, it is also necessary to discuss both the role of law in governance in general and which specific aspects of law we address here before discussing the role of law in adaptive governance. Law affects both the informal and the formal (governmental) aspects of governance. Thus, while law itself is part of formal governance, it may regulate private, nongovernmental behavior, and does so in the context of environmental laws such as the Endangered Species Act (regulating "take" of listed species), the Clean Water Act (regulating discharge of pollutants), and state water allocation law (regulating water use). Regulation of private behavior is not our primary focus here. Instead, we focus on the law that establishes the structure, authority, and process for the governmental aspect of governance. For example, how is authority distributed among local, state, tribal, and federal authorities; what authority do governmental agencies have to act in a particular situation; and what processes are agencies required to follow in taking that action? All of these processes are governed by law. Thus, because the law is pervasive in any governmental action, the guidelines for inquiry into the role of law in adaptive governance (Table 1) will resemble the criteria that various authors have developed for adaptive governance. The guidelines, however, are tailored to aid in integration of these criteria into governmental action through law governing the structure, capacity, and process of government. 
For the purpose of development of legal guidelines, we first extract from the various efforts to define and describe adaptive governance those aspects relevant to or influenced by the legal system. Second, we consider the concerns expressed by many of the same authors with the legitimacy and fairness of governmental involvement in governance that is less constrained, i.e., more adaptive.

In our first step, we find the conceptual model for adaptive governance developed by Dietz et al. (2003) of particular interest. The model is almost entirely composed of actions that may be facilitated by law: congruence of rules with ecological conditions, analytical deliberation and participation, clear boundaries and defined rights, enforced sanctions, mechanisms for dispute resolution, institutional variety, accountability, and nesting (i.e., the presence of common actors with similar authority playing a role in management across local to basin scales; Ostrom et al. 1961, Marshall 2007). We also find relevant the references to polycentricity; the ability to act at the bioregional scale, including devolution of authority to local actors; and the authority to experiment and learn (Ostrom 1999a, b, Folke et al. 2005, Huitema et al. 2009).

In our second step, we pay particular attention to the concerns raised with more flexible governmental action and government that enhances local participation and authority. Thus, numerous authors raise concerns that the implication of devolution of government to the local level inherent in calling upon local collaborative mechanisms will lead to issues in legitimacy, equity, and justice (Folke et al. 2005, Bingham 2009, Huitema et al. 2009, Lockwood et al. 2010, Cosens 2013; M. Lee, unpublished manuscript, http://citeseerx.ist.psu.edu/viewdoc/download? $\underline{\text { doi}}=10.1 .1 .202 .1474 \&$ rep=rep1\&type=pdf). Lockwood et al. (2010) recognize these concerns in developing governance principles for natural resources management. They include as important factors: legitimacy, transparency, accountability, inclusiveness, fairness, integration, capability, and adaptability, which are all concerns that the law governing the process of government has been developed to address in other contexts (Lockwood et al. 2010). These principles overlap with the development of principles for good governance (see e.g., Dublin Principles 1992, Rogers and Hall 2003, UNWWAP 2003, BorriniFeyerabend et al. 2013). The relationship between adaptive governance and good governance is an important question but is beyond our scope here. From the perspective of the role of law, it is simply important to note that these issues, broadly captured in the concept of legitimacy in administrative law (Esty 2006) and overlapping with principles of good governance, if not addressed in efforts to infuse government with adaptive capacity, those efforts will fail.

We recognize that this addition of principles of good governance overlays normative principles on a more scientifically based construction of adaptive governance and argue that this normative overlay is essential if the goal is effective governance, not just of isolated water resources, but also of water-based socialecological systems. Through the overlay of aspects of good governance, we place society, with its capacity for agency and social change, back into the quest for adaptive governance for social-ecological systems. Thus, in designing legal guidelines to intentionally facilitate adaptive governance, we rely on aspects of good governance and resilience theory as theoretical foundations.

\section{METHODS}

We began by participating in an interdisciplinary project to assess the resilience of six North American water basins; those assessments are available in the first Natural Resources and Environmental Law Edition of the Idaho Law Review (volume 51, issue 1: http://www.uidaho.edu/law/law-review/articles; Gunderson et al. 2017). The assessments illustrate that with the onset of climate change, some of the water supplies that are relied on in North America are close to or crossing irreversible thresholds that, once crossed, will alter the availability of natural ecosystem services and the adequacy of engineered infrastructure, potentially impairing existing water-based economies. However, the majority of the systems are currently in a state that, while vulnerable to climate change, present opportunities to increase capacity for adaptation if the appropriate resources and legal tools can be applied. Each basin assessment included a legal analysis of the governance structure and the role of law in that basin's management, often identifying key gaps or obstacles in the current governance systems.

Here, we used the compilation of the attributes of adaptive governance to extract related examples from the legal analysis in each of the six assessments. Three crucial questions for the role of law emerged from our analysis of watershed systems: What is the role of law in: (1) creating either a disturbance or window of opportunity in which adaptive processes may emerge, (2) eliminating barriers and facilitating adaptive processes, and (3) ensuring legitimacy in more adaptive governmental process?

We proceeded through an iterative process of translating the aspects of adaptive governance into guidelines for a complementary legal framework, returning to the basin assessments for application and further refinement. This process led to the development of guidelines for assessment of the legal framework for adaptation addressing each of the three questions. These legal guidelines were then tested and refined by applying them to a new water basin, the Lake Eyre basin and its connections to the Great Artesian basin, Australia (Cosens 2015). Discussion of the process of application of the guidelines to governance of a specific basin or landscape is beyond our current scope but can be found in the application to the Lake Eyre basin (Cosens 2015).

\section{GUIDELINES FOR THE ANALYSIS OF LEGAL FRAMEWORKS FOR WATER MANAGEMENT}

We use the questions on the role of law as an organizing mechanism to describe the legal guidelines.

Role of law in creating a disturbance or window of opportunity A disturbance sufficient to trigger the emergence of new approaches to governance may come from an ecological or social (political or economic) crisis, whereas a governance window of opportunity is thought to occur when the appropriate combination of problem, solution, and politics intersect to make change possible (Kingdon 1995, Olsson et al. 2006). Regulatory law creates a disturbance when its application results in feedback between environmental degradation and economic expectations by forcing individuals or entities to spend resources on preventing or cleaning up that degradation. Thus, listing of aquatic and riparian species under the U.S. Endangered Species Act or identification of water quality impaired streams under the U.S. Clean Water Act may force changes in behavior. While these statutes are generally associated with a top-down, command-and- 
control approach to environmental regulation, the Klamath (Chaffin et al. 2014a), Rio Grande (Benson et al. 2014), Anacostia (Arnold et al. 2014), and Platte (Birge et al. 2014) river assessments also indicate that the complexity of solving multiple regulatory issues in a manner acceptable to those affected may lead to the emergence of adaptive governance and novel solutions. In these examples, top-down regulation triggered innovation simply by presenting narrow solutions that were socially and economically unacceptable. Innovation may also occur when it is clear that existing law is inadequate to handle new changes in ecological systems. Thus, the combination of drought and the harsh reality of overallocation of water led to innovation, including water law reform, in Australia (Cosens 2016). Finally, law may also create a disturbance by shifting the allocation of power, as is evident in the Columbia River (Cosens and Fremier 2014) and Klamath basin (Chaffin et al. 2014a) assessments in which litigation over treaty fishing and water rights ultimately led formerly marginalized indigenous communities to new roles as comanagers of basin fisheries and as senior water rights holders. This congruence of a problem or disturbance, solution, and politics has led to numerous collaborative processes resulting in $>30$ settlements of Native American water rights (Native American Water Rights Settlement Database: http://repository.unm.edu/ handle/1928/32818; see also Cosens 2003, Chaffin et al. 2014a, Cosens and Chaffin 2016).

Nevertheless, not all of the settlements or the other examples of law as disturbance led to results that enhanced the ability of the related social-ecological system to respond to uncertainty and surprise. In some cases, collaboration and federal funding have led to increased optimization of water development for a narrow range of services and, therefore, increased system vulnerability to climate change (e.g., the Everglades assessment; Gunderson et al. 2014). At times, it is the law itself that leads to the choice of solutions that are less adaptive and more likely to enhance optimization of key services; for example, the inflexibility of Endangered Species Act regulations has created a barrier in both the Everglades (Gunderson et al. 2014) and Columbia (ThomasMorse 2012) systems. Thus, our exploration must consider the role of law in presenting barriers to adaptation and in facilitating adaptive processes.

\section{Role of law in eliminating barriers and facilitating adaptive processes}

Our effort to translate the criteria for adaptive governance and legitimacy or good governance, discussed above, into areas of inquiry relevant to the role of law in presenting barriers to adaptation and facilitating adaptive processes is captured in Table 1. We group these areas of inquiry into three categories that reflect the type of laws related to governmental action in environmental governance: structure, capacity, and process. Next, each category is explained in greater detail.

\section{Structure}

In reference to law, we use "structure" to refer to both the organizational design of regulatory and management systems and the legal basis of authority for management entities. Structure includes the manner in which law allocates authority among various levels and sectors of government (i.e., division of powers, responsibility as reflected in the various acts establishing an agency and delegating its authority) and the stability of the law regarding these arrangements. Hence, structure creates an organizational framework to balance accountability and efficiency with adaptive coordination and response, and provides the authority for adaptive coordination between government and society. Structural issues are likely to be one source of the problem when environmental governance is unable to adapt because of rigid top-down control or capture of management decisionmaking by narrow interests (e.g., Gunderson et al. 2014), or because the governance system is caught unprepared for change outside the historic range of variability. From an organizational standpoint, designing structure to promote adaptive governance requires attention to polycentricity, integration, and persistence.

\section{Polycentricity}

Polycentricity includes overlap in the authority to respond (referred to as redundancy) and complementarity (the presence of common actors with similar authority playing a role in management across local to basin scales, referred to as nesting; Ostrom et al. 1961, Marshall 2007). Promoting polycentricity for adaptive governance counsels us to keep the authority for decision-making as close to the individual as possible while still operating within a larger government framework that facilitates management implementation and achievement of long-term goals (referred to as subsidiarity; McGinnis 1999, Marshall 2007, Clarvis et al. 2014).

Nesting, in the context of government structure, means that lower levels of government have representation in higher levels. Nesting creates greater potential for adaptive response and integrated management when addressing environmental issues by taking advantage of the power of persistent social networks. These networks can build trust and knowledge and facilitate the flow of information and consistency of implementation (Krebs and Holley 2004, Bodin and Crona 2009). In turn, the chances of creating effective basin-wide management improve with increased overlap in the players, even in the absence of legal mandates. In contrast, communication gaps resulting from lack of overlap between intra- and interstate advisory bodies (both citizen and scientific), for example, may reduce trust and any sense that local input had value (Mitchell 2014), both of which are necessary to enhance adaptive response capability. More importantly for purposes of adaptation, nesting increases the likelihood that the relationship, shared knowledge, and networks will be in place to allow response to surprise. If, instead, policy makers try to set up a response framework for every possible outcome of climate change, the result would be expensive and potentially inadequate.

Subsidiarity means that the legal authority for decision-making is at the level closest to the scale of the resource or problem as possible, yet within the context of a government at larger scales that fosters the conditions for implementation of management decisions. Subsidiarity increases the likelihood of local participation and acceptance of decisions, use of local knowledge, and tailoring of response. It shortens the feedback loop from change in the ecosystem to those with the authority to respond. However, subsidiarity should not be read to mean the same thing as devolution of all authority to the local level (see e.g., Marshall 2007). Although greater local empowerment is needed in most North American water basins, without nesting of local authority within higher stabilizing levels of government, the authority to innovate and adapt may be destabilizing. 


\section{$\underline{\text { Integration }}$}

Integration refers to mutual cognizance and legal authority for coordination across all governance institutions that influence environmental management and regulation of physically connected resources (Arnold 2014, Cosens and Stow 2014). This concept has also been referred to in the law and resilience literature as connectivity (Clarvis et al. 2014). Integration reduces the possibility of unintended consequences and increases the likelihood that conflict will be addressed proactively. In the fragmented approach to water management in the United States, in which the law places water allocation at the state level (and states are only beginning to wrestle with the connections between ground and surface water), land use at the local level, aquatic and riparian endangered species at the federal level, and water quality at both the federal and state levels through cooperative federalism, integration may seem an impossible goal. However, our assessments illustrated that it is possible to address fragmentation through emergent adaptive processes (e.g., Chaffin et al. 2014a). Although, in general, fragmentation itself was not the initial driving force, once collaborative processes begin to emerge, the possibility of addressing multiple regulatory issues through an integrated solution may carry the process forward (e.g., Chaffin et al. 2014a, Cosens and Fremier 2014). The law should help to ensure that the authority to participate in and facilitate these integrating processes exists.

\section{Persistence}

Persistence encompasses stability in both the rules and actors involved in water management (see e.g., Mitchel 2014). Persistence fosters legitimacy and trust, potentially reducing the time needed to respond to surprise. It may seem counterintuitive that stability is an attribute of a legal system that fosters adaptive behavior. However, this reality highlights the difference between government and governance. Emergent adaptive governance that is capable of innovation, experimentation, and flexibility is likely to take place only within a stable, predictable governmental regime (Craig et al. 2017). However, it is important to contrast a government structure that provides stability and resources for local innovation with a stable government that provides control and resources to perpetuate a status quo that is unsustainable in light of changing circumstances (Garmestani and Benson 2013). The latter is referred to as a rigidity trap and may leave a watershed even more vulnerable to stressors such as climate change (e.g., Gunderson et al. 2014).

In sum, the balance is to create a stable government structure that does not obsessively mandate particular substantive outcomes. A key point regarding the role of law in facilitating the emergence of adaptive governance is this very important distinction between stability in the structure of government (e.g., the absence of war and government coups, continued commitment to the rule of law, and stable local and basin or landscape-scale government entities) and legal flexibility regarding the substantive governance goals for a given basin or ecosystem and the processes used to derive and achieve those goals.

\section{Capacity}

In general, capacity encompasses both the resources and authority to respond to change (Pahl-Wostl 2009) and increases the latitude within which adaptive processes may emerge.
Capacity consists of two important components: the ability to navigate ecological regime shifts, referred to as adaptive capacity (Gunderson 2000), and the right and resources of interested persons and groups to have a role in decision-making, referred to as participatory capacity (Raadgever et al. 2008, Huitema et al. 2009; see also Gunderson [2000], who uses an analogous definition of adaptive capacity in ecosystems). Increased capacity facilitates participation by those affected and provides the tools for innovation, experimentation, and evolution at appropriate levels. This is an important area for the role of law in management of landscape- or basin-scale systems. Not only must managers have legal authority to experiment, but they will need to have the legal authority to play a role in building the capacity of local communities to participate in developing solutions if they are to meet with success.

Adaptive capacity requires the resources (generally appropriated through a legislative act) and legal authority to respond to change and is reflected in the statutes, regulations, and practices of agencies (see e.g., Clarvis et al. 2014). Adaptive capacity allows a system of governance to adjust in the face of uncertainty and surprise. A number of legal sources effectively define, shape, and limit this capacity in water governance, including laws and policies defining: the authority of government to regulate water, including alteration of established water allocations and requirements in response to change; the authority and resources for agencies to facilitate the implementation of adaptive management in the face of uncertainty (see Craig and Ruhl [2014] for a draft administrative law for adaptive management); the authority and resources for government to facilitate collaborative adaptive planning (Arnold 2010, 2014); the resources and flexibility for local innovation; and the ability of individuals and private entities to adapt through water markets (see generally Cosens 2016).

Participatory capacity encapsulates both the ability of those affected by water management to participate in the development of its goals and the ability of water managers to implement goals developed through a participatory process. It includes the legal authority for agencies to use nongovernmental advisory bodies (including scientist and citizen-oriented committees), the legal process to appoint members, and the exercise of that authority. Participatory capacity reduces the likelihood of marginalization of portions of society and, in doing so, increases the likelihood that all aspects of a system will be considered in decision-making. As one example of the importance of participatory capacity, the 1992 United Nations Conference on Environment and Development led to Agenda 21, which identifies capacity as the crucial ingredient to sustainable development, states, "37.1 The ability of a country to follow sustainable development paths is determined to a large extent by the capacity of its people and its institutions as well as by its ecological and geographical conditions. Specifically, capacity-building encompasses the country's human, scientific, technological, organizational, institutional and resource capabilities" (United Nations 1992).

Although focused at the level of national governance, the listing of the necessary resources for capacity in Agenda 21 is equally applicable to local interests (Reed 2008). Communities must have the legal right of access to decision-making, as well as the knowledge, time, and resources to engage in the substance of decision-making (Bingham 2009). These conditions require the 
appropriate support in legislation and funding to secure capacity for those communities to act (Olsson et al. 2004). The role of law in promoting participatory capacity is to provide the requirement for public participation, judicial forums that can recognize and enforce the rights of those without power, and where appropriate, avenues for capacity building through the legislative allocation of resources and authority to facilitate local response (Working Group on Legal Frameworks for Public Participation 2013).

Capacity of both types appears to be the weakest link in North American water basins. It may be surprising that the wealthiest nation in the world (USA) scores so poorly in an area focused on "scientific, technological, organizational, institutional, and resource capabilities" (United Nations 1992:section 37.1). However, two legal factors are particularly relevant here. First, it is the federal level of government that has both relatively greater resources and far greater participatory capacity than the locallevel governments and other governance institutions. As a result, when federal legal mechanisms (e.g., U.S. Endangered Species Act and Clean Water Act) apply in a given basin, the absence of state and local legal avenues to develop solutions, the lack of federal level discretion to allow local coalitions authority to create new and more comprehensive solutions, and the lack of capacity of local actors to participate in efforts to tailor solutions may result in unsatisfactory or incomplete outcomes (Bingham 2009, 2010). In the best of circumstances, this will at least create an opportunity for emergence of innovation. There is, however, currently a dearth of legal mechanisms at any level that allow for alternatives to traditional environmental enforcement, which alternatives could enhance local adaptive capacity while maintaining stability and accountability toward achieving the goals that traditional enforcement mechanisms seek to achieve.

Nevertheless, there is also evidence that when the law allows for increased capacity, adaptive governance has a better chance of emerging. The substantial increase in participatory capacity of formerly marginalized communities as a result of recognition of rights through judicial processes and the emergence of local collaborative processes in several of our basin assessments may not be coincidental (e.g., Arnold et al. 2014, Benson et al. 2014, Birge et al. 2014, Chaffin et al. 2014a, Cosens and Fremier 2014). The experiment that California has embarked on through its new Sustainable Groundwater Management Act by setting state-level goals and mandating local groundwater planning while leaving the details to local entities may shed light on how future similar efforts should proceed (Kiparsky et al. 2016). If that experiment fails, the flaws (if stemming from areas within our legal framework as opposed to issues such as political will) are likely to arise from the absence of local capacity and accountability rather than the structural framework distributing legal authority between the state and local level.

Although capacity may be the weak link, no amount of capacity building will overcome a failure of process, the final area of inquiry into the legal framework. Process includes elements that both facilitate adaptation and ensure legitimacy but will be discussed under the latter category.

\section{Role of law in ensuring legitimacy in more adaptive governmental process}

Administrative process is a primary focus for implementation of elements of legitimacy and good governance through law. Good governance focuses on equity and justice and is reflected in legal requirements that the actions of government be legitimate, transparent, and inclusive (Franck 1988, Bodansky 1999, UNWWAP 2003, Esty 2006, Cosens 2013). It requires the availability of peaceful, just, and adequate means to resolve disputes about the allocation and use of finite resources. The basin assessments suggest that the tension between the competing needs for governance flexibility and economic stability presents a major barrier to adaptive governance (Craig et al. 2017). Attention to process can aid in tailoring the balance between flexibility and certainty to local needs and in a manner viewed as legitimate by affected parties.

Administrative law generally governs the process of governmental implementation of management and regulatory authority (Stewart 2003), and it is generally considered the locus of efforts to assure good governance, including legitimacy in governmental implementation of the law (Esty 2006, Cosens 2013). Law governing process in the United States may be found in the federal and state administrative procedure acts, but in the field of natural resources, that law may also be found in specific statutes and regulations directing agency action such as the U.S. National Environmental Policy Act (42 U.S.C. $\$ \$ 4321$ et seq.) or the consultation requirements in the Endangered Species Act (16 U. S.C. $\S \S 1531-1544$; see also Cosens 2013). Moreover, local governments in the United States exercise management and regulatory authority but are structured differently than federal and state governments and, thus, are subject to an adapted set of administrative law principles in fields such as land-use regulation (Juergensmeyer and Roberts 2013) and public health (Richards 2007).

That laws should be necessary to govern how agencies implement the law makes sense considering that the primary means of assuring governmental legitimacy in a democratic society is through the process of elections, whereas the massive administrative agencies are a step removed from that process. Although, in its current form, administrative law may contribute to the rigid, hierarchical nature of implementation of natural resources law by establishing a framework for uniform agency action, the underlying purpose is to ensure consistency, transparency, and accountability in implementation of the law by those not elected (Stewart 2003, Cosens 2013, Craig and Ruhl 2014). Drilling down to that purpose, then adjusting administrative law to allow room for more flexible procedures, can transform the way in which governmental entities interact with society while maintaining legitimacy (Cosens 2013).

We separate the process aspects necessary to assure good governance in the facilitation of adaptive governance into six categories: (1) legitimacy, (2) procedural justice, (3) problemsolving approach, (4) opportunity for reflection and learning, (5) balancing stability and flexibility, and (6) dispute resolution. Past work by team members has included procedural justice and balancing stability and flexibility under the category of legitimacy (Cosens 2013). However, in synthesizing the six basin assessments, these two areas rose to a level of importance that they warrant separate and focused consideration. We next address each of the six areas.

\section{Legitimacy}

Legitimacy pertains to the acceptance of authority because it is both perceived to be and is exercised appropriately (Tyler 2006). Legitimacy is necessary for public support of resource 
management and addresses the basic level of confidence and trust people have in those who govern. Legitimacy is of particular concern when authorizing greater flexibility, and thus discretion, in agency action (Cosens 2013, Craig and Ruhl 2014) and in devolving authority to local levels. Legitimacy is served through legal requirements for science-based decision-making, deliberation, accountability, transparency, consistency, stability, and review and recourse for those aggrieved by a governmental action.

In administrative law, legitimacy is enhanced through requirements of open meetings, availability of agency documents to the public, notice and public comment, promulgation of rules to assure that management and regulation are implemented in a consistent manner, and review of final agency action (Cosens 2013, Craig and Ruhl 2014). However, additional measures are necessary to facilitate the emergence of adaptive governance. First, authority to implement adaptive management as drafted by team members Craig and Ruhl (2014), with the resources to monitor the results of policy implementation, is considered an aspect of adaptive capacity but may also enhance legitimacy (Camacho 2009, Cosens 2013). The aspect of adaptive management involving adjustment in response to feedback from monitoring is designed to enhance learning and improve results from resource management, but it may also serve accountability goals (Cosens 2013, Craig and Ruhl 2014). Second, opportunities for public comment and even laws such as the U.S. National Environmental Policy Act, which requires federal agencies to submit information proactively on the potential environmental impacts of planned actions to the public for comment, are insufficient to facilitate emergence of adaptive governance. Authority to facilitate and participate in collaborative local processes and to factor the results into and even devolve certain decision-making to the local level is necessary (Bingham 2009, 2010).

Current law often actively interferes with these goals (Bingham 2009, Working Group on Legal Frameworks for Public Participation 2013). For example, in the United States at the federal level, the Federal Advisory Committee Act (5 U.S.C. App.) carefully constrains both the makeup and role of citizen advisory committees. Although the Federal Advisory Committee Act has been important in assuring that advisory committees are not captured by special interests and that federal decisions retain accountability, it is far too narrowly constructed to serve models of new governance and the emergence of adaptive governance (Bingham et al. 2005). It may be that in the short term, as federal and state governments experiment with the devolution of certain authority to local governance, authorization should precede on an ad hoc basis through legislative approval of place-based measures and where participatory capacity is strong (see also Marshall 2007). Such an ad hoc approach may assure legitimacy in implementing local adaptive governance solutions while maintaining the umbrella of federal and state standards and the provision of financial and scientific resources. It may create a testing ground and thus a bridge to more adaptive implementation of the law.

\section{Procedural justice}

Procedural justice includes attention to transparency, the right to seek review, and engagement at the appropriate level. Procedural justice is necessary to identify unintended consequences, check corruption, and avoid uneven application of the burden of adaptation. Although procedural justice overlaps with legitimacy (DeCaro and Stokes 2013), we consider it separately because our basin assessments revealed its critical importance in giving a voice to formerly marginalized communities. Substantive law on equal protection and due process played a role in redistributing power in the civil rights era (e.g., Arnold et al. 2014), and litigation concerning treaty rights has given voice to Native American communities (e.g., Chaffin et al. 2014a, Cosens and Fremier 2014, Cosens and Chaffin 2016). Under the category of process, we focus on the laws pertaining to governmental engagement with these communities. For indigenous communities, these laws must include requirements and policies to engage on a government-togovernment basis and to coordinate federal agency action in that effort.

\section{Problem-solving approach and opportunity for reflection and learning}

A problem-solving approach and the opportunity for reflection and learning are closely related when considering the law. A problem-solving approach requires science, openness to traditional and local ecological knowledge, and interest-based collaborative processes. It contrasts with political and ideological approaches that are not subject to compromise. It also contrasts with litigation, which resolves specific legal issues on a piecemeal basis and may not address the underlying problem. Nonetheless, litigation may serve as a stimulus or even a catalyst to problem solving when it is used to overcome barriers to problem solving created by entrenched interests and the refusal of governance systems to address ecological harms, social injustices, or other underlying problems (Arnold 2004, Karkkainen 2008, Arnold et al. 2014, Benson et al. 2014), a factor apparent in the rebalancing of power through recognition of Native American treaty rights and civil rights in several of our basin assessments (e.g., Arnold et al. 2014, Chaffin et al. 2014a, Cosens and Fremier 2014). The problem-solving approach is apparent in the process of community-based collaborative dialogue to address multiple issues of water allocation, quality, and management (e.g., Chaffin et al. 2014a).

A problem-solving approach to the development and incorporation of science in water management, as well as the capacity and opportunity for reflection and learning, will include resources (through legislative appropriations) to monitor and analyze information that tests not only the immediate results of management actions, but also the underlying assumptions of those actions, to facilitate a process referred to as double-loop learning (Pahl-Wostl 2009, Curtin 2014). The testing of scientific data, assumptions, and theories through the lens of local and traditional knowledge may even lead to questioning of the underlying belief systems, in a process referred to as triple-loop learning that is thought necessary for transformation of society (Pahl-Wostl 2009, Curtin 2014). At times, policy makers, regulators, and managers will need to give special and rapid attention to the feedback being provided by the public, including marginalized communities, and adapt governance actions quickly, as suggested by the recent example of slow government response to public complaints about the municipal water supply in Flint, Michigan. The role of law in this process is to provide the authority for use of a broader range of information that includes science as well as traditional and local ecological 
knowledge while retaining review processes that eliminate the incorporation of biased information (e.g., Craig and Ruhl 2014). The opportunity for reflection and learning assures that response to change will not be rote and that society will evolve with the approach to management.

Adaptive management is a useful tool in a problem-solving approach and incorporates a step involving reflection and learning. Its implementation will be aided by development of models for administrative law to provide the legal authority for its use by governmental agencies (Craig and Ruhl 2014). However, adaptive management is only one tool available, one that is well suited to management decisions in which uncertainty and controllability are high (Craig and Ruhl 2014) and in which the feedback necessary to inform adjustment is purely science based. Adaptive management is not appropriate when the decisionmaking is messy, involving consideration of both science and socioeconomic factors, or when aimed at other governance functions and processes such as setting broad goals and policies (e.g., planning) or building collaborative relationships. Planning approaches referred to as adaptive planning (Arnold 2010, 2014), collaborative process approaches such as Curtin's (2014) resilience design, and quasi-legislative or judicial processes such as participatory study circles and dispute resolution (Bingham et al. 2005) may be facilitated by providing agencies the authority to participate and even to facilitate and offer financial and scientific resources for such processes. However, we must again stress that while the law may incorporate and even mandate the processes discussed, many of the collaborative processes we seek as a result are emergent and cannot be directly legislated or mandated. Thus, we emphasize again that while the role of law can be to authorize a problem-solving approach and provide the process within which learning may take place, it cannot mandate critical thinking or learning. Our goal is simply to identify the means for the law to facilitate and provide space for these processes to emerge and authority for government to participate. At the very least, with these authorities available, law is less likely to stand in the way.

Balance of stabililty and flexibility

Balance of stability and flexibility recognizes that while adjustments must occur in the face of change, most social systems and particularly economic systems strongly prefer stability, and thus, stability is a primary goal of law. The tension between the competing needs for flexibility and economic stability presents a major barrier to adaptive governance (see Craig et al. 2017 for a more thorough discussion of this issue). The structural elements discussed above provide one avenue to strike this balance, but only if our call for subsidiarity, local collaboration, and devolution of governance is not equated with use of these terms in the United States to argue for local versus federal management of resources: polycentricity requires both (e.g., Ostrom 1999a,b, Thomson and Arroyo 2011). With multiple centers of decision-making ranging from the local to the national level, the higher levels, in addition to providing resources, may foster stability by creating substantive law that sets outer bounds (e.g., water quality standards under the Clean Water Act) and helpful processes such as requiring public participation or providing agency and judicial forums for review to assure accountability. Such bounding and procedural law may allow innovation and flexibility at the local or bioregional level without sacrificing overall stability.
Tools such as adaptive management are of particular concern to those with economic investments in the water resource and others who simply seek finality. As suggested by Cosens (2013), the legal authority or even mandate to negotiate time frames for adjustment that account for both biological and social concerns may aid in striking a balance among the social goals of economic and social stability, and finality and the reality of the need for adaptation in the face of ecological change. By building a renegotiation or amendment process into the relevant legal process, consideration of the need for change in governance becomes normalized and stabilized, much as regularly scheduled elections allow for political change without social or economic upheaval.

\section{Dispute resolution}

Dispute resolution requires appropriate legal forums (also reflected in structure), processes, and rules for resolution, and is essential as water scarcity and ecological regime shifts become more common in many parts of the world as climate change unfolds. Although collaborative processes are the starting point for the emergence of adaptive governance, there may come a point when voluntary agreement is not possible. In these circumstances, unless a system for resolving issues is designed and agreed upon beforehand, conflict is likely. Providing a forum and process for resolving conflict and making final, binding decisions on tradeoffs regarding scarce resources is an essential role for higher levels of government (Ostrom 1990, Dietz et al. 2003), and it is through the law that they do this. In addition, availability of dispute resolution forums and rules that equitably distribute the pain of scarcity and other climate change effects may provide incentive to engage in collaborative processes.

Appropriate conflict resolution requires attention to two aspects controlled by how the law is written: establishment of a forum that will ensure fairness and an opportunity to be heard; and clear and transparent rules for resolving the conflict that are consistent with societal and ecological goals (Tyler 2006). In the context of water resources in the United States, conflict resolution must occur at both the state level, which holds authority over water allocation, and the federal level, which asserts authority over water quality, endangered species, interstate water allocation, and domestic participation in international water allocation. The judicial and administrative forums available at both federal and state levels to challenge decisions generally satisfy the first aspect of conflict resolution. It is in the establishment of rules that adjustments are needed. We leave these substantive aspects of $U$. S. environmental and water law to a future publication.

\section{CONCLUSION}

At the outset we asked three questions of the role of law. We conclude with the salient points on each.

1. What is the role of law in creating either a disturbance or a window of opportunity in which adaptive processes may emerge?

- The application of regulatory law may create a disturbance because of the inconvenience or cost of compliance, or because of the intersection of multiple regulatory requirements that are not adequately addressed through piecemeal compliance. Collaborative processes may emerge through efforts to find more comprehensive solutions. 
- Law may be used to alter the distribution of power. The presence of new voices in environmental management and the consequences of a shift in power among resource users and interests may lead to emergent processes to seek novel solutions.

2. What is the role of law in eliminating barriers and facilitating adaptive processes?

- The laws establishing the structure of governmental authority can be adjusted to allow for increased coordination and integration across sectors and levels of environmental management with representation of lower levels within higher level advisory bodies, a measured degree of persistence in terms of those involved in management, and attention to placing authority at the level closest to the resource scale as possible while nesting this authority within a higher level of oversight and assistance.

- Law may be used to enhance adaptive capacity by providing the authority to choose among the options that include tools such as adaptive management, adaptive planning, regulated water markets, and the resources for their implementation.

- Law may be used to authorize the provision of both financial and knowledge-based resources to ensure the capacity for local participation.

3. What is the role of law in ensuring legitimacy in more adaptive governmental process?

- Law may be used to provide the authority for governmental entities to use tools such as adaptive management that iterate toward an agreed upon solution.

- Law may be used to provide the authority for governmental entities to engage broadly with the public through venues that do not constrain the breadth and availability of public participation, yet provide stability through clearly defined procedural rules and transparent governmental decisionmaking.

- Law may be used to provide the resources for governmental entities to monitor the social-ecological system at issue, the flexibility to respond to feedback from monitoring, and the authority to test scientific understanding of a system through the lens of local knowledge.

- Law may be used to provide the authority to focus resources for innovation and experimentation at the local level and the scale of the social-ecological system while maintaining sufficient state- and federal-level oversight and goals to provide stability.

- Law may be used to provide forums for dispute resolution that include facilitation of alternative approaches to managing conflict for complex, multistakeholder problems.

Although law has often been viewed as a constraint on adaptation, it has proven highly adaptive over time. Collectively, the responses to the questions regarding the role of law illustrate numerous avenues to facilitate adaptation. We emphasize that while our framework is generalized, its application is context specific. We further emphasize that if adaptation is necessary for society to navigate the changes and transitions that will accompany climate change, and law dictates the structure, capacity, and process through which government acts, then analysis of the role of law in adaptive governance when faced with environmental conflict and the implementation of any necessary reform becomes imperative. In considering the role of law, we believe that legal reform will fail to achieve its objectives if it does not pay attention to legitimacy and other aspects of good governance. Integrating reform to achieve adaptation with reform to ensure legitimacy increases the likelihood of both acceptance and success in navigating the changes to come.

Responses to this article can be read online at: http://www.ecologyandsociety.org/issues/responses. $\mathrm{php} / 8731$

\section{Acknowledgments:}

We thank the National Socio-Environmental Synthesis Center (SESYNC) under funding from the National Science Foundation DBI-1052875 for continued support of the Adaptive Water Governance Project, which made this work possible by funding the collaboration among the authors and other AWG team members. We appreciate the support of the Idaho Water Resources Research Institute in providing funding toward the publication of this article. Barbara Cosens also thanks the Goyder Institute for Water Research in South Australia and the Flinders University Visiting Professor in Public Sector Policy and Management Program. Her participation in the program was the first opportunity to apply these concepts to a new water basin, the Lake Eyre basin in Australia, which contributed to their refinement. The views expressed in this paper are those of the authors and do not represent the views or policies of the U.S. Environmental Protection Agency.

\section{LITERATURE CITED}

Arnold, C. A. 2004. Working out an environmental ethic: anniversary lessons from Mono Lake. Wyoming Law Review 4 (1):1-55.

Arnold, C. A. 2010. Adaptive watershed planning and climate change. Environmental and Energy Law and Policy Journal 5 (2):417-488. [online] URL: https://www.law.uh.edu/eelpj/ publications/5-2/07Arnold.pdf

Arnold, C. A. 2014. Adaptive water law. Kansas Law Review 62 (4):1043-1090. [online] URL: https://law.ku.edu/sites/law.drupal. ku.edu/files/docs/law review/v62/6\%20KLR $\% 20$ Site $\% 20$ Arnold Final $\%$ 20Press.pdf

Arnold, C. A., O. O. Green, D. DeCaro, A. Chase, and J.-G. Ewa. 2014. The socio-ecological resilience of an eastern urbansuburban watershed: the Anacostia River basin. Idaho Law Review 51(1):29-90.

Benson, M. H., D. Llewellyn, R. Morrison, and M. Stone. 2014. Water governance challenges in New Mexico's Rio Grande valley: a resilience assessment. Idaho Law Review 51(1):195-228.

Bingham, L. B. 2009. Collaborative governance: emerging practices and the incomplete legal framework for public and stakeholder voice. Journal of Dispute Resolution 2009(2):1-58. http://scholarship.law.missouri.edu/jdr/vol2009/iss2/2 
Bingham, L. B. 2010. The next generation of administrative law: building the legal infrastructure for collaborative governance. Wisconsin Law Review 2010(2):297-356.

Bingham, L. B., T. Nabatchi, and R. O'Leary. 2005. The new governance: practices and processes for stakeholder and citizen participation in the work of government. Public Administration Review 65(5):547-558. http://dx.doi.org/10.1111/j.1540-6210.2005.00482. $\underline{\mathrm{X}}$

Birge, H. E., C. R. Allen, R. K. Craig, A. S. Garmestani, J. A. Hamm, C. Babbitt, K. Nemec, and E. Schlager. 2014. Socialecological resilience and law in the Platte River basin. Idaho Law Review 51:229-256.

Bodansky, D. 1999. The legitimacy of international governance: a coming challenge for international environmental law? American Journal of International Law 93(3):596-624. http://dx. doi.org/10.2307/2555262

Bodin, Ö., and B. I. Crona. 2009. The role of social networks in natural resource governance: What relational patterns make a difference? Global Environmental Change 19(3):366-374. http:// dx.doi.org/10.1016/j.gloenvcha.2009.05.002

Borrini-Feyerabend, G., N. Dudley, T. Jaeger, B. Lassen, N. P. Broome, A. Phillips, and T. Sandwith. 2013. Governance of protected areas: from understanding to action. Best Practice Protected Area Guidelines Series 20. International Union for Conservation of Nature, Gland, Switzerland. [online] URL: http://cmsdata.iucn.org/downloads/governance web 1.pdf

Camacho, A. E. 2009. Adapting governance to climate change: managing uncertainty through a learning infrastructure. Emory Law Journal 59(1):1-77. [online] URL: http://law.emory.edu/elj/ content/volume-59/issue-1/articles/governance-climate-change-uncertaintyinfrastructure.html

Clarvis, M. H., A. Allan, and D. M. Hannah. 2014. Water, resilience and the law: from general concepts and governance design principles to actionable mechanisms. Environmental Science and Policy 43:98-110. http://dx.doi.org/10.1016/j. envsci.2013.10.005

Chaffin, B. C., R. K. Craig, and H. Gosnell. 2014a. Resilience, adaptation, and transformation in the Klamath River basin social-ecological system. Idaho Law Review 51(1):157-193.

Chaffin, B. C., H. Gosnell, and B. A. Cosens. 2014b. A decade of adaptive governance scholarship: synthesis and future directions. Ecology and Society 19(3):56. http://dx.doi.org/10.5751/ ES-06824-190356

Cosens, B. A. 2003. Water dispute resolution in the west: process elements for the modern era in basin-wide problem solving. Environmental Law 33:949-1018.

Cosens, B. A. 2013. Legitimacy, adaptation, and resilience in ecosystem management. Ecology and Society 18(1):3. http://dx. doi.org/10.5751/ES-05093-180103

Cosens, B. 2015. Application of the Adaptive Water Governance Project to management of the Lake Eyre basin and its connections to the Great Artesian basin. Flinders University and Goyder Institute for Water Research, Adelaide, Australia. [online] URL: http://www.goyderinstitute.org/uploads/FU\%20LEB \%20GAP\%20ReportWEB.pdf
Cosens, B. 2016. Water law reform in the face of climate change: learning from drought in Australia and the western United States. Environmental and Planning Law Journal 33(4):372-387.

Cosens, B., and B. C. Chaffin. 2016. Adaptive governance of water resources shared with indigenous peoples: the role of law. Water 8(3):97. http://dx.doi.org/10.3390/w8030097

Cosens, B., and A. Fremier. 2014. Assessing system resilience and Ecosystem Services in Large River Basins: a Case Study of the Columbia River Basin. Idaho Law Review 51:91-125.

Cosens, B. A., and C. A. Stow. 2014. Resilience and water governance: addressing fragmentation and uncertainty in water allocation and water quality law. Pages 142-175 in A. S. Garmestani and C. R. Allen, editors. Social-ecological resilience and law. Columbia University Press, New York, New York, USA.

Craig, R. K., A. S. Garmestani, C. R. Allen, C. A. Arnold, H. Birgé, D. A. DeCaro, A. K. Fremier, H. Gosnell, and E. Schlager. 2017. Balancing stability and flexibility in adaptive governance: an analysis of tools available in U.S. environmental law. Ecology and Society: in press

Craig, R. K., and J. B. Ruhl. 2014. Designing administrative law for adaptive management. Vanderbilt Law Review 67:1 http://dx. doi.org/10.2139/ssrn.2222009

Curtin, C. G. 2014. Resilience design: toward a synthesis of cognition, learning, and collaboration for adaptive problem solving in conservation and natural resource stewardship. Ecology and Society 19(2):15. http://dx.doi.org/10.5751/ES-06247-190215

DeCaro, D. A., and M. K. Stokes. 2013. Public participation and institutional fit: a social-psychological perspective. Ecology and Society 18(4):40. http://dx.doi.org/10.5751/ES-05837-180440

Dietz, T., E. Ostrom, and P. C. Stern. 2003. The struggle to govern the commons. Science 302:1907-1912. http://dx.doi.org/10.1126/ science. 1091015

Dublin Principles. 1992. The Dublin statement on water and sustainable development. United Nations, New York, New York, USA. [online] URL: http://www.un-documents.net/h2o-dub. $\underline{\mathrm{htm}}$

Esty, D. C. 2006. Good governance at the supranational scale: globalizing administrative law. Yale Law Journal 115 (7):1490-1562. http://dx.doi.org/10.2307/20455663

Folke, C., T. Hahn, P. Olsson, and J. Norberg. 2005. Adaptive governance of social-ecological systems. Annual Review of Environment and Resources 30:441-473. http://dx.doi.org/10.1146/ annurev.energy.30.050504.144511

Franck, T. M. 1988. Legitimacy in the international system. American Journal of International Law 82(4):705-759. http://dx. doi.org/10.2307/2203510

Garmestani, A. S., and M. H. Benson. 2013. A framework for resilience-based governance of social-ecological systems. Ecology and Society 18(1):9. http://dx.doi.org/10.5751/es-05180-180109

Green, O. O., A. S. Garmestani, C. R. Allen, L. H. Gunderson, J. B. Ruhl, C. A. Arnold, N. A. J. Graham, B. Cosens, D. G. Angeler, B. C. Chaffin, and C. S. Holling. 2015. Barriers and bridges to the integration of social-ecological resilience and law. Frontiers in Ecology and the Environment 13(6):332-337. http://dx. doi.org/10.1890/140294 
Gunderson, L. H. 2000. Ecological resilience - in theory and application. Annual Review of Ecology and Systematics 31:425-439. http://dx.doi.org/10.1146/annurev.ecolsys.31.1.425

Gunderson, L., B. A. Cosens, B. C. Chaffin, C. A. (T.) Arnold, A. K. Fremier, A. S. Garmestani, R. K. Craig, H. Gosnell, H. E. Birge, C. R. Allen, M. H. Benson, R. R. Morrison, M. C. Stone, J. A. Hamm, K. Nemec, E. Schlager, and D. Llewellyn. 2017. Regime shifts and panarchies in regional scale social-ecological water systems. Ecology and Society 22(1):31. http://dx.doi. org/10.5751/es-08879-220131

Gunderson, L. H., A. Garmestani, K. W. Rizzardi, J. B. Ruhl, and A. Light. 2014. Escaping a rigidity trap: governance and adaptive capacity to climate change in the Everglades social ecological system. Idaho Law Review 51:127-156.

Gunderson, L. H., and C. S. Holling, editors. 2002. Panarchy: understanding transformations in human and natural systems. Island Press, Washington, D.C., USA.

Holling, C. S. 1973. Resilience and stability of ecological systems. Annual Review of Ecology and Systematics 4:1-23. http://dx.doi. org/10.1146/annurev.es.04.110173.000245

Huitema, D., E. Mostert, W. Egas, S. Moellenkamp, C. PahlWostl, and R. Yalcin. 2009. Adaptive water governance: assessing the institutional prescriptions of adaptive (co-)management from a governance perspective and defining a research agenda. Ecology and Society 14(1):26. http://dx.doi.org/10.5751/es-02827-140126

Juergensmeyer, J. C., and T. E. Roberts. 2013. Land use planning and development regulation law. Third edition. West, St. Paul, Minnesota, USA.

Karkkainen, B. C. 2008. Getting to "let's talk": legal and natural destabilizations and the future of regional collaboration. Nevada Law Journal 8(3):811-829. [online] URL: http://scholars.law.unlv. edu/nlj/vol8/iss $3 / 3$

Kingdon, J. W. 1995. Agendas, alternatives, and public policies. Second edition. Harper Collins, New York, New York, USA.

Kiparsky, M., D. Owen, N. G. Nylen, J. Christian-Smith, B. Cosens, H. Doremus, A. Fisher, and A. Milman. 2016. Designing effective groundwater sustainability agencies: criteria for evaluation of local governance options. Center for Law, Energy, and the Environment, University of California, Berkeley, California, USA. [online] URL: https://www.law.berkeley.edu/ research/clee/research/wheeler/groundwater-governance-criteria/

Krebs, V., and J. Holley. 2004. Building sustainable communities through social network development. Nonprofit Quarterly 11:46-53. [online] URL: https://nonprofitquarterly.org/2004/03/21/ building-sustainable-communities-through-social-network-development/

Lockwood, M., J. Davidson, A. Curtis, E. Stratford, and R. Griffith. 2010. Governance principles for natural resource management. Society and Natural Resources 23(10):986-1001. http://dx.doi.org/10.1080/08941920802178214

Marshall, G. 2007. Nesting, subsidiarity, and community-based environmental governance beyond the local scale. International Journal of the Commons 2(1):75-97. http://dx.doi.org/10.18352/ ijc. 50
McGinnis, M. D., editor. 1999. Polycentric governance and development: readings from the workshop in political theory and policy analysis. University of Michigan Press, Ann Arbor, Michigan, USA.

Mitchell, B. 2014. Evolving regional, integrated and engagement approaches for natural resources management in South Australia. Flinders University and Goyder Institute for Water Research, Adelaide, Australia. [online] URL: http://www.goyderinstitute. org/uploads/documents/publications/2014/Bruce\%20Mitchell-WEB. pdf

Olsson, P., C. Folke, and F. Berkes. 2004. Adaptive comanagement for building resilience in social-ecological systems. Environmental Management 34(1):75-90. http://dx.doi.org/10.1007/s00267-003-0101-7

Olsson, P., L. H. Gunderson, S. R. Carpenter, P. Ryan, L. Lebel, C. Folke, and C. S. Holling. 2006. Shooting the rapids: navigating transitions to adaptive governance of social-ecological systems, Ecology and Society 11(1):18. http://dx.doi.org/10.5751/ es-01595-110118

Ostrom, E. 1990. Governing the commons: the evolution of institutions for collective action. Cambridge University Press, Cambridge, UK.

Ostrom, V. 1999a. Polycentricity (part 1). Pages 52-74 in M. D. McGinnis, editor. Polycentricity and local public economies: readings from the workshop in political theory and policy analysis. University of Michigan Press, Ann Arbor, Michigan, USA.

Ostrom, V. 1999b. Polycentricity (part 2). Pages 119-138 in M. D. McGinnis, editor. Polycentricity and local public economies: readings from the workshop in political theory and policy analysis. University of Michigan Press, Ann Arbor, Michigan, USA.

Ostrom, V., C. M. Tiebout, and R. Warren. 1961. The organization of government in metropolitan areas: a theoretical inquiry. American Political Science Review 55(4):831-842. http:// dx.doi.org/10.2307/1952530

Pahl-Wostl, C. 2009. A conceptual framework for analysing adaptive capacity and multi-level learning processes in resource governance regimes. Global Environmental Change 19(3):354-365. http://dx.doi.org/10.1016/j.gloenvcha.2009.06.001

Raadgever, G. T., E. Mostert, N. Kranz, E. Interwies, and J. G. Timmerman. 2008. Assessing management regimes in transboundary river basins: Do they support adaptive management? Ecology and Society 13(1):14. http://dx.doi. org/10.5751/es-02385-130114

Reed, M. S. 2008. Stakeholder participation for environmental management: a literature review. Biological Conservation 141 (10):2417-2431. http://dx.doi.org/10.1016/j.biocon.2008.07.014

Repko, A. F. 2011. Interdisciplinary research: process and theory. Second Edition. Sage, Thousand Oaks, California, USA.

Richards, E. P. 2007. Public health law as administrative law: example lessons. Journal of Health Care Law and Policy 10:61-88.

Rogers, P., and A. W. Hall. 2003. Effective water governance. TEC Background Papers 7. Global Water Partnership, Stockholm, Sweden. [online] URL: http://www.gwp.org/Global/ToolBox/ 
Publications/Background $\% 20$ papers $/ 07 \% 20$ Effective $\% 20$ Water $\%$ 20Governance $\% 20 \% 282003 \% 29 \%$ 20English.pdf

Stewart, R. B. 2003. Administrative law in the twenty-first century. New York University Law Review 78(2):437-460. [online] URL: http://www.nyulawreview.org/sites/default/files/pdf/NYULawReview-78-2$\underline{\text { Stewart.pdf }}$

Thomas-Morse, C. 2012. When courts run regulated rivers: the effects of scientific uncertainty. Pages 148-174 in B. Cosens, editor. The Columbia River Treaty revisited: transboundary river governance in the face of uncertainty. Oregon State University Press, Corvallis, Oregon, USA.

Thomson, V. E., and V. Arroyo. 2011. Upside-down cooperative federalism: climate change policymaking and the States. Virginia Environmental Law Journal 29(1):1-61.

Tyler, T. R. 2006. Psychological perspectives on legitimacy and legitimation. Annual Review of Psychology 57:375-400. http://dx. doi.org/10.1146/annurev.psych.57.102904.190038

United Nations. 1992. United Nations Conference on Environment and Development, Rio de Janerio, Brazil, 3 to 14 June 1992: agenda 21. United Nations, New York, New York, USA. [online] URL: https://sustainabledevelopment.un.org/content/documents/Agenda21. pdf

United Nations System Task Team on the Post-2015 UN Development Agenda (UNSTT). 2012. Governance and development: thematic think piece. United Nations, New York, New York, USA. [online] URL: http://www.un.org/millenniumgoals/ pdf/Think $\% 20$ Pieces/7 governance.pdf

United Nations World Water Assessment Program (UNWWAP). 2003. Water for people, water for life: the United Nations world water development report. United Nations, New York, New York, USA. [online] URL: http://www.unesco.org/new/en/naturalsciences/environment/water/wwap/wwdr/wwdr1-2003/downloads/

Walker, B., C. S. Holling, S. R. Carpenter, and A. Kinzig. 2004. Resilience, adaptability and transformability in social-ecological systems. Ecology and Society 9(2):5. http://dx.doi.org/10.5751/ ES-00650-090205

Walker, B., and D. Salt. 2006. Resilience thinking: sustaining ecosystems and people in a changing world. Island Press, Washington, D.C., USA.

Working Group on Legal Frameworks for Public Participation. 2013. Making public participation legal. National Civic League, Denver, Colorado, USA. [online] URL: http://ncdd.org/rc/wpcontent/uploads/MakingP2Legal.pdf 